\title{
The Role of Islam Rahmat lil 'Alamin as the Solution For Exclusive Life in Indonesia
}

\author{
1Eka Apriani, 2Irwan Fathurrochman, 3Hendra Harmi \\ Institut Agama Islam Negeri (IAIN) Curup \\ 1ekaapriani_90@ymail.com \\ 2inhamna@gmail.com \\ 33hendra3_harmi@yahoo.co.id
}

\begin{abstract}
Islam has given mercy to the development of languages, traditions, culture and arts found in various regions in Indonesia. Islam rahmatan lil alamin appears in the form of development and wealth of knowledge. However, Indonesia is not a religious country, but religious values are very dominant and very animating to the people in their personal lives, family, community, nation and state. Moreover, in the context of Indonesia, a country that is predominantly Muslim and becomes the foundation of the advancement of the Islamic world in the future, the spirit of religion cannot be separated from its people. In this case Islam appears as a religion that provides solutions in exclusive life, so as to create harmony that can lead to harmony in life. So the conclusion that we can take is that Islam as a religion that has the mission of rahmatanlil 'alamin must be the basis for every individual and group of Muslims to be tolerant and act well in spreading peace to all parties wherever and whenever.
\end{abstract}

Keyword: Islam, rahmatan lil alamin, exclusive life

\section{Introduction}

Islam is the religion of rahmatan lil 'alamin, which means that Islam is a religion that brings grace and prosperity to the entire universe, including animals, plants and jinn, especially human beings. The statement that Islam as the religion of rahmatan lil 'alamin is contained in the word of Allah SWT:

AJIS: Academic Journal of Islamic Studies vol. 3, no. 2, December 2018 IAIN Curup - Bengkulu | p-ISSN 2580-3174, e-ISSN 2580-3190 Available online: http://journal.staincurup.ac.id/index.php/AJIS 




And We have not sent you (O Muhammad) except as a mercy to the worlds ". (QS.Al-Alnbiya: 107)

According to Quraish Shihab, the implication of the verse above contains a very broad meaning. This verse mentions four main things:

1. Apostle/messenger of Allah in this case is the Prophet Muhammad

2. who sent him in this case is Allah,

3. those sent to them are all human (al-'alamin)

4. treatises, all of which signal their properties, namely the nature of grace very large as understood from the form of nakirah/indefinite from the word Islam forbids humans to act arbitrarily against Allah's creatures, just look at the word, plus by describing the scope of the target within all time and place.

Furthermore he explained that, personality formation of prophet Muhammad SAW is the will of Allah has made attitude, speech, deeds even all of his totality with the teachings he conveyed, because even his teachings are a total grace and thus, fused teachings and conveyors of teachings, merged with treatises and apostles, and because the apostle peace be upon him is the concrete manifestation of the morality of the Koran. Because of that the texts of his teachings speak to the heart and mind human. He was born to fulfill spirituality and human rationality, two elements possessed by each personal self. Characteristics and quality is the basics of Islamic teachings themselves. Characteristics and quality of teaching principles Islam which contains universal values, among others, relates to monotheism, ethics and morals, forms and systems of government, social politics and economy, democratic participation (deliberation), social justice, peace, education and intellectualism, work ethic, environment and so on. 
The word "Islam as religion means" peace, which comes from the word "salam". Allah's Word in surah al-Anfal verse 61:

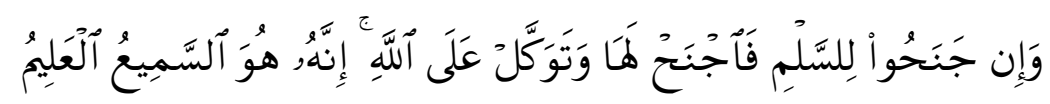

And if they incline to peace, then incline to it [also] and rely upon Allah. Indeed, it is He who is the Hearing, the Knowing. (QS AlAnfal; 61).

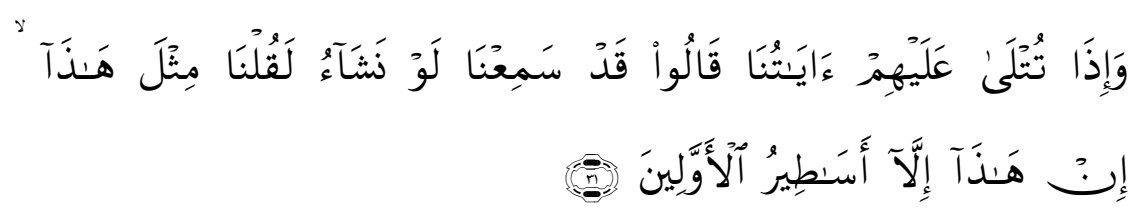

And when Our verses are recited to them, they say, "We have heard. If we willed, we could say [something] like this. This is not but legends of the former peoples."(Surat al-Anfal; 31).

Islam also means "welfare, with the origin of the word " salaam ". The Word Allah in surah Al-Zumar verse 73 which is true: "And those who are devoted to their Lord are brought to heaven groups too. So that when they come to heaven and the doors were opened, and said unto them their guards, "Welfare is bestowed upon you, bless you, then enter this heaven, while you dwell therein. "

Whereas according to Arkoun, the word "Islam" is interpreted in language France with the meaning of "submissive/obedient" (istislam). This translation according to Arkoun absolutely not true (Putro, 1998). The believer is not submissive and obedient in before Allah; but he felt a vibration of love for Allah and a sense of desire awaken to what he commanded by revelation. Allah exalting man to him, so that in him arose well thought towards the Creator. Therefore there is a voluntary relationship, longing and good guess between Him and His creation.

In this sense, Islam must be seen as a religion full of spiritual content for the sake of human spiritual satisfaction. He is religious because of his need for remember Allah, not because Allah wants 
people to remember Him. So Islam is a voluntary act as implied in the original word "salam", "to be safe, awake, and intact". Someone can't run Islam for the sake of others, and because of that in Islam coercion belief is not allowed. In line with Arkoun, Izutsu is a renowned scientist from Japan. Izutsu stated that, in pre-Islamic times, the word Islam meant -giving - nothing to lose \|\| or something very noble. In al- The Koran is transformed into an act of surrender which contains autonomy for the sake of self or human ego itself. In the basic sense, " Muslim " (said the actor from Islam, "someone who is surrendering himself ) is the person who makes surrender and his manifest commitment to Allah and his Prophet voluntarily (izudsu, 1964).

From this description it is clear that Allah is actually not requires human surrender. Acts solely is the act of following the natural law prescribed by Him. People who don't follow it mean "sinning against themselves." Allah themselves are not affected by their ignorance. "Whoever does goodness he does for himself, and whoever does evil, then he did to himself. And Allah does not apply dzalin above His servant" (Al-Quran Letter Fusshilat: 46)

To emphasize the identity of the submission of a Muslim (Islam) to Allah by following the rules of nature, the Koran likens submission of shadows by prostration in prayer, "Only to Allah (obey) everything that is in the sky and on earth is good by its own volition or forced (and also shadow shadows in the morning and evening day. " ( Al-Quran SurahArRadu: 15) Allah's response from submission to his commandments is Altruistic human social harmony, "Say (O Rosul):" I do not ask you any wages for my appeal except (that you must) love relatives (fellow humans) 'and those who do good will us add to him goodness to his kindness. 


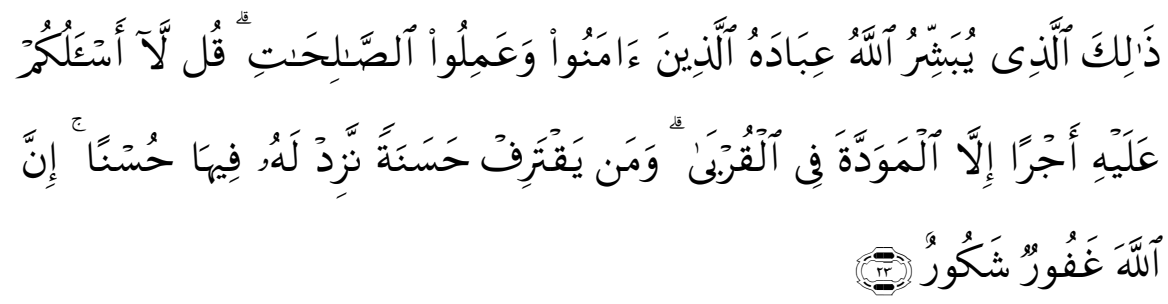

It is that of which Allah gives good tidings to His servants who believe and do righteous deeds. Say, [O Muhammad], "I do not ask you for this message any payment [but] only good will through kinship." And whoever commits a good deed - We will increase for him good therein. Indeed, Allah is Forgiving and Appreciative. (QS. As Syura 23)

These are the letters of the alphabet which lie at the beginning of a portion of the Al-Qur'an letters such as: Alif laam miim, Alif laam raa, Alif laam miim shaad and so on. Among the commentators there are those who give their understanding to Allah because they are considered to include the verses of mutasyaabihaat, and some interpret them. the group that interprets those who see it as the name of the letter, and some argue that the letters of the alphabet are useful to attract the attention of the Listeners to pay attention to the Qur'an, and to indicate that the Qur'an was revealed from Allah in Arabic composed of letters alphabetical letters. if they do not believe that the Qur'an was revealed from Allah and only made Muhammad alone, then try them to make a kind of Qur'an.

When Islam is present in the Arab region as a new movement that tries renewing established religion, Islam is hated and fought, even his followers were persecuted. The Prophet's phase in Mecca was thick with this atmosphere. Post moved to Medina by agreeing to the Medina charter between Muslims and non-Muslims are concrete evidence that Islam is a tolerant religion, can stand with other religions without terror, pressure and coercion. Islam's majority religion seeks to protect itself by preventing it the growth of other religious movements in it. If a new religion is successful 
and gets a foothold, then the old religion that has been established persecutes new religion.

This tragic history also occurs in culture and ethnicity. It signs of health and life of the majority who seek to develop and absorb minorities. There is nothing wrong with that universal. However what is wrong is the method of absorption, use of force, coercion and tyranny, "player $\mathrm{t} \|$ or " attraction $\|$ to achieve his goal. Practically, all world religions are guilty of this --- all but Islam. Because Islam has a unique mission theory from other beliefs. 13See Ismail R. Al-Faruqi\& Lois Lamya Al-Faruqi, Atlas of Islamic Culture ( Mizan, 1998: h 217-219)

\section{The Meaning of Exclusivism}

The term "exclusivism" comes from the word "exclusive". In terms of terminology, exclusive is defined as "separate from the others", "special", or "not included". Whereas "exclusivism" means a social perspective understand that has a tendency to separate themselves from society (KBBI, 1990 ).

While the word Exclusivity is a derivative that contains a closed meaning and feels that the truth belongs only to the group and the group, so the mistakes that arise are at the root of the conflict. It is acknowledged that Indonesia is not a religious country, however religious values are very dominant in animating its people in their personal lives, family, community, nation and state. Moreover, in the context of Indonesia, a country that is predominantly Muslim and becomes the foundation of the advancement of the Islamic world in the future, the spirit of religion cannot be separated from its people. So it is not surprising if religion in various aspects and manifestations gets great attention in this country.

\section{Problems and Social Influence on Understanding Rahmatan}

\section{Lil' Alamin.}


In a historical perspective, the struggle of Islam as a religion with socio-cultural reality there are two possibilities. First, Islam is capable give the uot-put (results, influence) to the environment in the sense of giving basic philosophy, direction, encouragement and guidelines for changing society the formation of new social reality. Second, Islam is influenced by existence, style and direction.

This means that Islamic actuality is determined by sociocultural system. In this second possibility, the Islamic system is nature static or dynamic but less meaningful for socio-cultural change. The mission of Islam is to try to transform dynamics of dynamics owned, and this is constantly pressing for existence social transformation. Islamic ideological has ideals that uphold amarma'ruf and nahimunkar in society within the framework of faith in Allah. While amarma'ruf means humanization and emancipation, nahimunkar is an effort to liberate. And because these two tasks are inside framework of faith, then humanization and liberation are two sides cannot be separated from transcendence. In every society, with structure and any system, and in any historical stage, ideals for humanization, emancipation, liberation and transcendence will always motivate Islam.

The discourse on relations between the state and Islam is always interesting to discuss, not only in the beginning of the nation's founding but also in this last period. The discussion about this discourse in the early days of the nation's establishment was part of the efforts made by the founding fathers in exploring the values that had been embedded in the community to be formulated as an ideology which became the foundation of nation and state.

Thus, Islam must be seen as a dialectical system which includes aspects of ideality and reality; includes belief dimension (creed) which in the form of monotheism and implemented into the praxis dimension which includes culture, social and cultural as well as other Islamic traditions. As a base of the whole series of worship in Islam, tauhid is not only concerned the problem is simply 
theological propositions, but also an implication logically which is creative, dynamic. For every Muslim, Islam that has revelation should be plenary frame of reference for his entire life. Islam, with thus is a complete unifying religion (a religion of Complete integration).

In the context of history, for the first time we see teachings concerning human development through complete integration with him itself, with society, with the universe, and that this integration based on the existence of Allah Almighty in all his ex . Islamic teaching is a perfect and comprehensive conception, because it covers all aspects of human life, however only the outline only, both worldly and ukhrawi. Theological Islam, is a system of values and teachings that are divine and transcendent. Whereas from the sociological aspect, Islam is a phenomenon of civilization, cultural and social reality in human life.

Today boarding schools are faced with many challenges, including the modernization of Islamic education. Islamic education has relationship directly. Character in education is the spirit in the Islamic education. Islamic education and character in education create students with better characters and values. It is clear that Islamic education with detailed guidance will never leave the content of al-Qur'an and al-Sunnah that in line with the character in education, in example building the students with good moral. ${ }^{1}$

The system and institutions of the boarding school have been modernized and adapted to the demands of development, especially in the institutional aspects which will automatically influence the determination of the curriculum that refers to the institutional goals of the institution namely students' character. The problem that arises is whether the boarding school in determining the curriculum must merge with the demands of the

1 I Fathurrochman, E Apriani, Pendidikan Karakter Perspektif Pendidikan Islam Dalam Upaya Deradikalisasi Paham Radikal, (POTENSIA: Jurnal Kependidikan Islam, 2017,http://ejournal.uin-suska.ac.id/index.php/potensia/article/view/2726). 
present, or rather it must be able to maintain it as a characteristic of boarding school which in many ways is more able to actualize its existence amidst the demands of society. ${ }^{2}$

In a social context, understanding religion cannot stand alone. Social, environmental, educational and political factors take part in affect one's religious understanding. So that, moderate or radically, one's understanding is not merely influenced by the doctrine of teaching religion, but it is also influenced by various factors which in turn will give birth to social attitudes and behavior. Views and attitudes of Islamic groups towards multiculturalism cannot be separated from the interaction of ummah (in group), either individually or in groups with communities outside the group (out group).

The social changes that occur often are a response from an interaction that gives rise to a reaction or attitude. The Word of Allah Surah al-Baqarah verses 256-257, which is true: "There is no compulsion to (enter) religion (Islam). Indeed it is clear the right from the wrong path. Therefore, whoever is aware of thought and believe in Allah, then indeed he has held on knots that are very strong and will not break. Allah is Hearing again knowing. Allah is the Protector of those who believe. He expels them from darkness (disbelief) to light (faith). And those who disbelieve, their protectors are Satan, who expels them from light to darkness (disbelief). They are residents of hell. They will abide therein. " (AlBaqarah: 256-257).

SayyidQutb in his commentary "FiiDzilalilQur" JuzIII, explains that, sentence is expressed in the form of an absolute negative "there is no compulsion to (enter) religion (Islam)." This expression is for "Nafililjinsi" nullify all kinds, that is, confirm all forms of coercion in the world in the reality of the life of the ummah. Furthermore Sayyid Qutub explained that, the sentence:

\footnotetext{
2Fathurrochman, "Implementasi Manajemen Kurikulum Dalam Upaya Meningkatkan Mutu Santri Pondok Boardig school Hidayatullah/Panti Asuhan Anak Soleh Curup."
} 
which means: "Verily the right path is clear from the road the heretic ", is that faith is the right way, which is already humans should like and want it. Whereas, disbelief is a misguided path, which humans should have run away from and take care of him.

The problem is so practical. So, not humans contemplate the pleasure of faith with a clear and bright mind, with a calm and peaceful heart, with a mind that is attentive and feeling clean and with good and straight social order, expressed in the form of diverse agendas and movements. Starting from accommodating to a system that is good (and rejects the bad) that there is a desire to change the system. Cooperation (cooperation) in the form of accommodation carried out on cultural patterns and community behavior that is considered good (not in conflict with aqidah and shariah).

While differentiation is done to confirm the differences in status and role of Muslims or non-Muslim groups. They consider Islam to be superior in terms of morals and values truth. Therefore, their agenda is to uphold Islamic law and sharia. SayyidQutb, Fi Zhilalil Qur'an, (Beirut: Dar al-Syuruq, 1992, Juz III / h. 221) which encourages the development and improvement of quality of life?

It is not human beings contemplating faith in this way but rather will get the right and righteous way of life, which will not reject it except the fool. Namely, people who leave the road the right one leads to the wrong path, leaving a clue to error, and prioritize darkness, shock, humiliation and error rather than calmness, peace, well-being, heights and nobleness. Then, clarified and reaffirmed the nature of faith with very clear boundaries, "Therefore, whosoever denies to thought and believes in Allah, then indeed he has held on to the knot of a rope which is very strong and not will break up ". Surely this denial must be shown to what is it must be denied, namely ابو.Whereas faith must be shown to those who really deserve faith, namely Allah. 
Whoever arbitrarily kills birds, or other animals smaller than him, then Allah will ask forresponsibility for him".It's so beautifulthat Islam isn't!With animal, it shouldn't be arbitrary, especially with humans .

Imagine if humans understand and practice the teachings of Islam, it will be truly beautiful and peaceful this world. The Prophet Muhammad sallallaahu 'alaihiWasallam was sent with the teachings of Islam, then Islam is the rahmatanlil'alamin, Islam is a blessing for all humans. mercy means gentleness combined with compassion. Or in other words grace can be interpreted with love (Narrated by Al Bukhari in Al 'Ilal Al Kabir 369).

Rejang Lebong Regency is a district in Bengkulu province. The district has an area of $1,515.76 \mathrm{~km}^{2}$ and a population of around 257,498 inhabitants The capital city is Curup. The district is located on the slopes of the Bukit Barisan mountain range and is $85 \mathrm{~km}$ from the city of Bengkulu which is the provincial capital. The majority of the population of Rejang Lebong regency is the Rejang tribe, which amounts to $43 \%$, followed by the Javanese who are migrants with an amount of around $35.2 \%$. The indigenous tribe besides the Rejang tribe is the Lembak tribe. Although dominated by the Rejang and Javanese tribes, the population in Rejang Lebong is very diverse both in terms of ethnicity, race and religion. This happened because since the Dutch era precisely in 1904, Bengkulu Province was opened to transmigration areas.

Rejang Lebong is one of the regencies in Bengkulu Province where the majority of the population is Islam. A variety of cultures develop here, like riding horse, martial art and so on. So, what is the view of Islam as rahmatan lil 'alamin towards this developing culture. Of course actually is considering the essence of these activities. If there are many disadvantages rather than benefits, it is better to leave. Even that is what Islam teaches. Such a situation is what Islam wants to overcome. That is to change a life full of suffering to be full of happiness, a life that is full of obstruction and 
hostility into a life full of grace and affection. This fact is reinforced by the hard-nosed mission of the Prophet Muhammad as explained in the Qur'an, surah al-Anbiya (21) verse 107 which states: I am not sent but to bring mercy to all nature.

The main religion adopted by the people in Rejang Lebong is Sunni Islam with a percentage of $97 \%$. Then other religions in a smaller composition (Protestant Christians $0.87 \%$, Catholics $0.48 \%$, Kong $\mathrm{Hu}$ Chu $0.01 \%$, Buddhas 0.25\%, and Hindus 0.02\%). There are also some residents who still adhere to the flow of tribal beliefs, around $0.04 \%$ So that it cannot be denied that the majority of the population is Muslim, the habits or customs of the residents have been mixed or acculturated with religious values.

In depth, Islam entered the Rejang Lebong Regency in the 16th century through the Palembang region. Islam began to be broadcast in the Rejang region through marriage between one of the leaders of the Islamic kingdom in Indrapura Malaka and the royal princess in this region. Furthermore, Islambegan to develop at that time, when the community began to flock to Islam, which previously they embraced the beliefs of Animism and Dynamism, namely believing in objects believed to have mystical powers and the spirits of ancestral spirits. Until the mid-19th century there were still remnants of old beliefs in the interior, but at the end of the 19th century there were no more complete adherents. The Rejang community has embraced Islam, even though the old way is still being carried away.

Furthermore, the life of Muslims in Rejang is currently not much different from the early era of Islam in this region. At this time Islam has become the religion with the most followers in this district. With the percentage of almost $97 \%$ of the people embracing Islam. This greatly affects community life in this region. But on the other hand, citizens in this region before embracing Islam they have had the beliefs and culture that they have embraced before so that this affects the lives of their diversity. Or it 
can be said that in its development Islam in Rejang Lebong has been acculturated with the existing culture.

For example, in the tradition before entering the month of Ramadan, residents will hold a tasyakuran program by holding a recitation or yasinan. In the process the recitation activity will begin with the burning of incense, which is intended for the ancestor's soul. This habit is influenced by the people's belief that burning incense will make God give a kindness to their ancestor. But in practice the reading or spells with vernacular language along with the entry of Islam, this was changed to the reciting of the Qur'anic verses.

The other example is that the customary law system in the form of fines and village washing is still maintained today. This is due to the compatibility of the Rejang tradition with Islamic teachings, the Rejang tribe has changed their previous beliefs into the teachings of Islam. Until now, their culture is known as Islamic culture in Rejang Lebong.

On the other hand, with the diversity of race, ethnicity and religion in the regency of Lebong, it also influences the social order in the community. Communities with Muslim majority make the Rejang Lebong district very thick with religious values, although this is still wrapped up in traditions that develop in the community. But this does not become an obstacle in religious harmony in society. Rejang lebong Muslims strongly uphold religious tolerance, this can be proven, with the establishment of other religious congregations in the region with Muslim populations. Not only that, in the celebration of religious holidays even the Islamic community in Rejang Lebong strongly holds the principle of religious harmony where Muslims usually invite or hold open houses for non-Muslims. Vice versa, when there is a big celebration of religious nonMuslims, Muslims are invited to.

From some of the explanations above, it is explained that Islam in the Rejang Lebong is a majority religion. Furthermore, the 
process of developing Islam in Rejang Lebong has been acculturated with the culture or beliefs held by the residents of Rejang Lebong. And the last is that the Rejang Lebong community is a community that holds fast to diversity and religious harmony. The Rejang Lebong community is very tolerant with other nonMuslim citizens.

\section{Conclusion}

The discourse on relations between the state and Islam is always interesting to discuss, not only in the beginning of the nation's founding but also in this last period. The discussion about this discourse in the early days of the nation's establishment was part of the efforts made by the founding fathers in exploring the values that had been embedded in the community to be formulated as an ideology which became the foundation of nation and state. Islam is a religion that has the mission of rahmatan lil 'alamin which should be the basis for every Muslim group to be tolerant and act well in spreading peace to all parties in anywhere and anytime.

In addition, Harfin Muhammad Zuhdi states that Islam teaches that all human beings are one community. Humans have the right to life, property rights, justice rights, honor rights, the right to freedom of religion, and the right to life moral. These rights are the right of Allah's gift that must be implemented under any circumstances. Islam emphasizes justice (justice) and fair treatment for all people, including even to the enemy "do not let your hatred of a group make you unjust, apply it is fair because it is closer to taqwa. Judging from the study of Islam rahmatan lil alamin, it must prioritize the principle of the equatability and equality, so that social life in Islamic reviews does not teach distortion of the meaning of exclusivity as a community.

\section{References}


Amin, DR KH Ma'ruf. "ISIS: Gerakan Kekhalifahan Islam Global Dan Tantangan Bagi Nkri Dan Islam Rahmatan Lil'alamin," t.t.

Azra, Azyumardi, Mereka mengambil Alih dalam Penegakan Hukum, dalam Khazanah Suplemen Republika, 1 Juni 2002.

Barida, Muya, danUniversitas Ahmad Dahlan. "Inklusivitas Vs Eksklusivitas: Pentingnya Pengembangan Wawasan Kebangsaan Dalam Mewujudkan Kedamaian Yang Hakiki Bagi Masyarakat Indonesia," 2017

E. Shepard, William, "Islam and Ideology: Towards Typology" dalam Internasional Journal of Middle Eastern Studies, No. 19, 1987. Bandingkan dengan Bruce Lawrence, Defenders of God: The Fundamentalist Revolt Against The Modern Age, New York: I.B. Tauris, 1990.

Fathurrochman, Irwan. "Implementasi Manajemen Kurikulum Dalam Upaya Meningkatkan Mutu Santri Pondok Boarding school Hidayatullah/Panti Asuhan Anak Soleh Curup." TADBIR: Jurnal Studi Manajemen Pendidikan 1, no. 1 (19 Juni 2017): 85-104. https://doi.org/10.29240/jsmp.v1i1.216.

Fathurrochman, Irwan, and Eka Apriani. "Pendidikan Karakter Prespektif Pendidikan Islam dalam Upaya Deradikalisasi Paham Radikal." POTENSIA: Jurnal Kependidikan Islam 3, no. 1 (2017): 122-142.

Indawatik, Rita, Drajat Tri Kartono, danTrisniUtami. “EksklusifitasSiswa (Studi Fenomenologi Konstruksi Sosial Pola Eksklusifitas Siswa Pada Kelas Unggulan Di Sma Muhammadiyah 1 SragenTahunAjaran 2011/2012)." JurnalAnalisaSosiologi 2, no. 1 (15 Januari 2018). https://doi.org/10.20961/jas.v2i1.17386.

Izutsu, T. (1964).God and Man in The Koran: Semantics of the Koranic Weltanschauung. Tokyo: KICLS.

Nata, Abuddin, Studi Islam Komprehensif, (Jakarta:Prenada Media Group, 2011), cet. I.

Putro, S. (1998). Muhammad Arkoun Tentang Islam Modernitas.Jakarta :Paramadina. 
Rahman, Yusuf, Islam and Society in Contemporary Indonesia, (Jakarta: Faculty of Graduate Studies Syaruf Hidayatullah Jakarta, 2005), cet. I.

Zuhdi, Muhamad Harfin. "Fundamentalisme Dan Upaya Deradikalisasi Pemahaman Al-Qur'an Dan Hadis." Religia, 3 Oktober 2017. https://doi.org/10.28918/religia.v13i1.176. 